\title{
Possible sensor applications of selected DNA-surfactant complexes
}

\author{
Ewelina Nowak $^{1}$ (1) $\cdot$ Anna Wisła-Świder ${ }^{1} \cdot$ Gohar Khachatryan $^{1} \cdot$ Maciej Fiedorowicz $^{1} \cdot$ Krzysztof Danel $^{1}$
}

Received: 26 February 2018 / Revised: 7 September 2018 / Accepted: 9 April 2019 / Published online: 19 April 2019

(c) The Author(s) 2019

\begin{abstract}
Although much research has been performed on DNA complexes carrying long alkyl chains (C10, C16, and C18), there is no information about physicochemical characterization of synthesized composites with allyl imidazole-based ionic liquids and quaternary ammonium salts with $n$-butyl chains. Here, complexes were synthesized by ion-exchange reactions between sonicated DNA and three ionic liquids (ILs) formed from two imidazole-based compounds, 1-allyl-3-methylimidazolium bromide (Amim) or 1-butyl-3-methylimidazolium bromide (Bmim), and from the quaternary ammonium salt tetra- $n$-butylammonium bromide (TBAB). Signals in UV-Vis, IR, and CD spectra indicating inclusion of small molecules into the DNA structure confirmed the formation of DNA complexes. Both IR and CD spectra indicated that the B-form conformation of the DNA did not change after the formation of the complexes. Similarly, X-ray diffraction patterns revealed that the formation of IL-DNA complexes did not change the structure of native B-form DNA. Molecular weight $\left(M_{w}\right)$ and radii of gyration $\left(R_{\mathrm{g}}\right)$ values of IL-DNA complex chains, established by high-performance size exclusion chromatography coupled with multiangle-laser light-scattering with a differential refractive index detector, were significantly lower than those values found for native DNA molecules due to DNA fragmentation by sonication during complex formation and the direct effects of the IL on the DNA. Scanning electron microscopy images indicate the formation of nanofibres in DNA-Amim and DNABmim complexes, whereas the formation of nanowires was found in samples of DNA-TBAB complexes. Changes in optical properties confirmed by UV and photoluminescence make DNA-IL complexes potential candidates for biosensor application.
\end{abstract}

Electronic supplementary material The online version of this article (https://doi.org/10.1007/s00249-019-01367-2) contains supplementary material, which is available to authorized users.

Ewelina Nowak

e.nowak@ur.krakow.pl

1 Department of Chemistry, University of Agriculture, 122

Balicka Str., 30-149 Cracow, Poland 


\section{Graphical abstract}
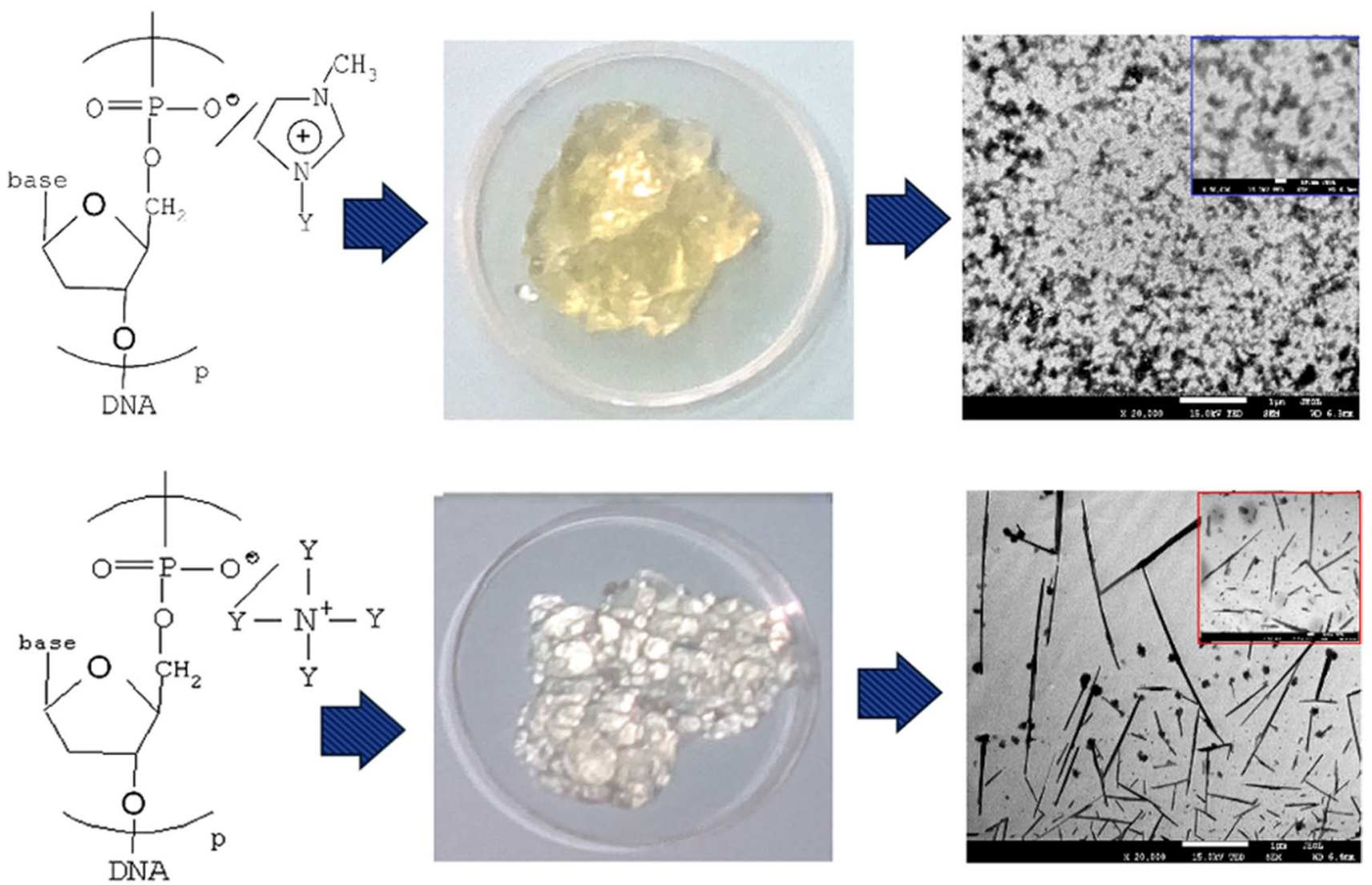

Keywords Deoxyribonucleic acids $\cdot$ Biopolymers $\cdot$ Imidazoles $\cdot$ Ionic liquids $\cdot$ Ion-exchange reactions

\section{Abbreviations \\ DNA' \\ DNA \\ DNA-Amim means \\ DNA-Bmim means \\ DNA-TBAB means \\ Before sonication \\ After sonication \\ DNA modified with Amim \\ DNA modified with Bmim \\ DNA modified with TBAB}

\section{Introduction}

In recent years, great interest has been attracted by studies of deoxyribonucleic acid (DNA) molecules as an inexpensive, renewable material for numerous applications in organic LEDs and laser structures. DNA is of interest for its unique charge migration and other physical properties and for potential application in optoelectronic devices (Grote et al. 2005; Wang et al. 2001; Hagen et al. 2006; Steckl 2007; Yu et al. 2007; Krupka et al. 2008; Kitazawa et al. 2009; Steckl et al. 2011; Sahraoui et al. 2011), mostly via DNA-based biopolymers possessing low electromagnetic and tunable electrical

resistivity, and ultralow optical microwave loss (Rau et al. 2011; Subramanyam et al. 2003; Hagen et al. 2007).

Over the last few years, a number of optoelectronic devices have been fabricated using DNA. These DNA complexes normally possess high resistivity and efficiency, making them useful in organic field-effect transistors (OFETs), organic light-emitting diodes (OLEDs), organic lasers, nonlinear optical (NLO) polymer electro-optic modulators and nanofibers (Sun et al. 2009; Zalar et al. 2011; Hung et al. 2012). A considerable number of publications have focused on the fabrication of photonic devices based on DNA-CTMA (cetyltrimethylammonium chloride) complexes. This is due to the fact that such structures have self-assembly properties and could produce nanometer-scale supramolecular assemblies (Aga et al. 2013; Pratap Reddy et al. 2017; Gajria et al. 2011).

Natural DNAs are water soluble and hygroscopic biopolymers. To use DNA for device fabrication, we have to modify the molecules and make DNA soluble in organic solvents. Usually, we replace sodium $\left(\mathrm{Na}^{+}\right)$or hydrogen $\left(\mathrm{H}^{+}\right)$ions of DNA with long alkyl quaternary ammonium $\left(\mathrm{Q}^{+}\right)$ions. This 
modification leads to the formation of $\mathrm{Q}^{+} \mathrm{DNA}^{-}$complexes which are soluble in organic solvents. Recently, much attention has been given to the interaction between DNA and cationic surfactants, to develop unique compounds (Smirnova and Safonova 2012; Lindman et al. 2014). According to literature reports (Jumbri et al. 2014, 2016; Zhao 2015), an essential role in complex stabilization is played by the electrostatic attraction between the surfactant cation's headgroups and DNA phosphate groups. Despite this fact, the hydrophobic interactions of DNA-cation alkyl chains are very important (Zhao 2015).

In this research, we investigated interactions between negatively charged DNA and three different cationic surfactants with short chains (allyl, $n$-butyl, and methyl). Complexes of two imidazole-based ionic liquids and a quaternary ammonium salt with pure salmon DNA were synthesized by ionexchange reactions. Although much research has been performed on DNA complexes carrying long alkyl chains $\left(\mathrm{C}_{10}\right.$, $\mathrm{C}_{16}, \mathrm{C}_{18}$ ) (Kwon et al. 2012; Sivapragasam et al. 2016), there is no information about physicochemical characterization of synthesized composites with allyl imidazole-based ionic liquids and quaternary ammonium salts with $n$-butyl chains.

Our paper describes synthesis and physicochemical properties of novel DNA-based materials, including gels and gel particles, taking into account the general understanding of the interactions between DNA and oppositely charged agents, and in particular their phase behavior. It is noteworthy that cationic surfactants have enabled particularly efficient control over the properties of DNA-based particles (Costa et al. 2008).

Ionic liquid (IL)-DNA complexes were characterized with UV-Vis, photoluminescence and IR spectrometric techniques, and Scanning Electron Microscopy (SEM). The absolute molecular weights $\left(M_{w}\right)$, radii of gyration $\left(R_{\mathrm{g}}\right)$, and data from circular dichroism spectra and X-ray diffraction (XRD) experiments of the obtained complexes are also given. Our work shows the differences in physicochemical properties of our IL-DNA complexes compared to pure DNA and other conjugates which determine their potential applications in optoelectronics and biosensors.

\section{Materials and methods}

\section{Materials}

DNA from Salmon testes (purity $=96 \%$ ) comprising oriented fibers was purchased from Ogata Research Laboratory (Aoba Chitose, Hokkaido, Japan). The absorbance ratio $\left(\mathrm{A}_{260} / \mathrm{A}_{280}\right)$ was around 1.8 to ensure that DNA is sufficiently free of protein (Guo et al. 2015). Ionic liquids (surfactants): 1-allyl-3-methylimidazolium bromide ( $\geq 97$, $0 \%$ ) (Amim), 1-butyl-3-methylimidazolium bromide
( $\geq 97,0 \%$ ) (Bmim), and tetra- $n$-butylammonium bromide $(\geq 98,0 \%)$ (TBAB), which in the molten state behaves like an ionic liquid, were purchased from Sigma-Aldrich (Sigma-Aldrich Sp. z.o.o, Poland).

The deionized water (Resistivity $18.2 \mathrm{M} \Omega \times-\mathrm{cm}$ ) used in the experiments was obtained from a Millipore water purification system. All the other chemical reagents were of analytical grade and were used without any further purification.

\section{Methods}

\section{Synthesis of IL—DNA complexes}

At room temperature, DNA was completely dissolved in deionized water under constant stirring for $24 \mathrm{~h}$ to obtain the final DNA concentration of $2 \%(\mathrm{w} / \mathrm{w})$. Then, DNA was sonicated for $100 \mathrm{~min}$ in ultrasonic cleaner (Sonic-14, $2 \times 400 \mathrm{~W}$, Poland) in an ice bath to avoid the degradation of pure DNA. Sonication was necessary to obtain a lower viscosity of the solutions and to expose reactive centers of DNA which could improve the contact between DNA and ILs. Ionic liquids were dissolved in deionized water to obtain a concentration $0.0008 \mathrm{M} / \mathrm{mL}$. The $5 \%(\mathrm{w} / \mathrm{w})$ solution of ionic liquid was added dropwise to an aqueous DNA solution. In such conditions, the DNA formed a pregel (Lee et al. 2008, 2009). After $24 \mathrm{~h}$ stirring of pre-gel DNA solution, coagulation mixture containing ionic liquid and ethanol (weight ratio 9:1) was added. The coagulation time was about $30 \mathrm{~min}$, and coagulated microfibers formed were then washed several times with ethanol and deionized water.

The procedure of obtaining each DNA complex $\left(\mathrm{Q}^{+} \mathrm{DNA}^{-}\right)$with imidazole-based ionic liquids (Amim, Bmim) and quaternary ammonium salt (TBAB) is presented in Fig. S1.

According to the literature (Cui and Zhu 2006; Cui et al. 2006, 2008), schematic reactions of synthesis and formation of complexes of DNA with imidazole-based ionic liquids (Amim, Bmim) and quaternary ammonium salt (TBAB) are presented in Figs. 1 and S2, respectively.

\section{FTIR-ATR spectrophotometry}

The FTIR-ATR spectra of the DNA complexes were recorded in the range of $4000-700 \mathrm{~cm}^{-1}$ at a resolution of $4 \mathrm{~cm}^{-1}$ using a MATTSON 3000 FT-IR (Madison, Wisconsin, USA) spectrophotometer. The instrument was equipped with a 30SPEC $30^{\circ}$ Reflectance adapter fitted with the MIRacle ATR accessory from PIKE Technologies Inc., Madison, Wisconsin, USA. 
Fig. 1 Scheme of ion-exchange reactions of imidazole-based ionic liquids (Amim, Bmim) with $\mathrm{H}^{+}$ions from salmon DNA
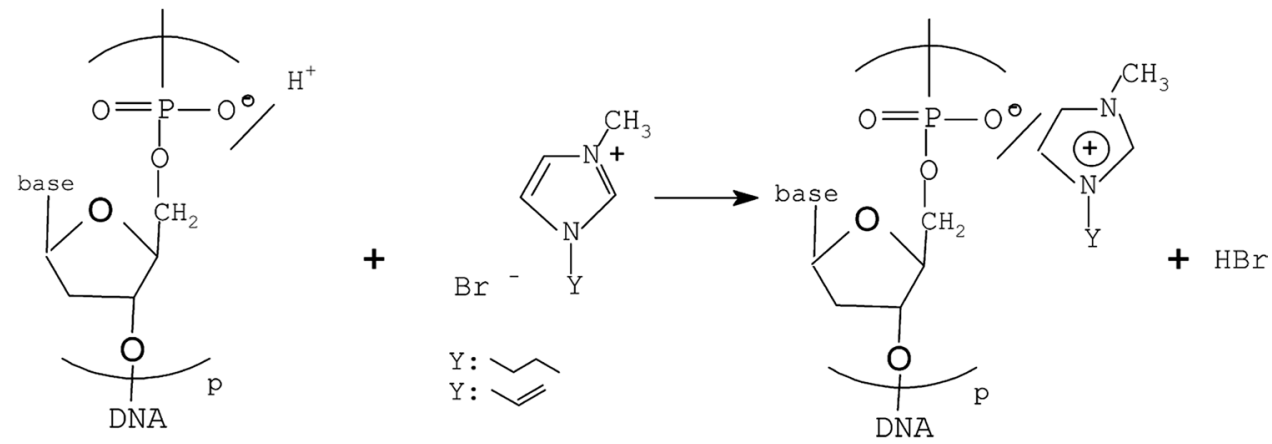

High-performance size exclusion chromatography (HPSECMALLS-RI)

Determination of molecular weight and radii of gyration of DNA and their derivatives were measured by means of high-performance size exclusion chromatography (HPSEC) coupled with multiangle laser light-scattering (MALLS) detector and differential refractive index (RI) detector. The high-performance size exclusion chromatography system and methods of measurement are described in our previous publication (Nowak et al. 2012).

Calculation of the weight-average molecular weight $\left(M_{w}\right)$ and radius of gyration $\left(R_{\mathrm{g}}\right)$ used Astra 4.70 software (Wyatt Technology, Santa Barbara, California, USA). A Berry plot with third-order polynomial fit was applied for the calculation of $M_{w}$ and $R_{\mathrm{g}}$ values (Hanselmann et al. 1996; Bello-Perez et al. 1996).

\section{Scanning electron microscopy (SEM)}

A scanning electron microscope (JEOL 7550) equipped with a TED (Transmission Electron Diffraction) and LEI (Lower Secondary Electron) detectors was used to analyze the morphology of synthesized DNA-surfactant structures. DNA-ionic liquid solutions were dispersed in deionized water to obtain $0.5 \mathrm{mg} / \mathrm{mL}$ concentration and stirred for $12 \mathrm{~h}$. Samples for SEM microscopy were prepared after drop-coating $10 \mu \mathrm{L}$ of the sample on a carbon coated grids 200 mesh $\mathrm{Cu}$ (100) (TAAB Laboratories, England, United Kingdom).

\section{UV-Vis absorption spectrophotometry}

The UV-Vis absorption spectra of the DNA samples were recorded using a Shimadzu 2101 scanning spectrophotometer in the range of 190-900 nm using $1 \mathrm{~mL}$ cells. Transmission spectra were measured in the same range as absorption. Concentration of solution was $100 \mu \mathrm{g} / \mathrm{ml}$.

\section{Photoluminescent spectroscopy}

Photoluminescence measurements of DNA and DNA complexes were performed at room temperature $\left(25^{\circ} \mathrm{C}\right)$ using an F-7000 FL HITACHI spectrophotometer operating with $1200 \mathrm{~nm} / \mathrm{min}$ scan rate. Fluorescence intensity was recorded upon excitation at wavelength $310 \mathrm{~nm}$, using excitation and emission slits at $10 \mathrm{~nm}$. Concentration of solutions DNA and IL-DNA complexes was $100 \mathrm{mg} / \mathrm{ml}$.

\section{Circular dichroism spectra}

Near-UV circular dichroism measurements were performed to assess changes in structure between native DNA and DNA complexes. Circular dichroism spectra of DNA and DNA-ionic liquid surfactants were recorded using a JASCO J-710 (Jasco, Japan) spectrophotometer (upgraded to a J-715). Each of the samples (except DNA) were dissolved in DMSO to obtain $100 \mu \mathrm{g} / \mathrm{ml}$ concentration. Spectra were recorded from 250 to $350 \mathrm{~nm}$ at a scanning rate of $50 \mathrm{~nm} / \mathrm{min}$ in a Hellma quartz cuvette with $1 \mathrm{~mm}$ path length, with a sample concentration of $100 \mu \mathrm{g} / \mathrm{ml}$.

\section{X-ray diffraction (XRD)}

X-ray powder diffractometry was used to determine the crystalline or amorphous structure of all samples. Samples of DNA and DNA-surfactant complexes were prepared as coagulated microfibers (gel state). Equilibrated samples were sealed between two tape foils to maintain stable water content throughout the measurement. Diffraction diagrams were recorded using $X$ 'pert-type Phillips diffractometer (Phillips, Groeningen, The Netherlands) with a cobalt lamp of $\lambda=1.78896^{\circ} \mathrm{A}(30 \mathrm{~mA}$ and $40 \mathrm{kV})$ and in a scanning region of $2 \theta$ from $5^{\circ}$ to $60^{\circ}$ in $0.02^{\circ}$ intervals. 


\section{Results and discussion}

\section{FTIR spectra}

The FTIR spectrum of pure DNA (DNA') is presented in Fig. 2. In the spectrum, several strong vibrational bands centered at 1057, 1221, 1456, and $1643 \mathrm{~cm}^{-1}$ are observed. According to the literature (Taillandier et al. 1985; Taillandier 1990; Taillandier and Liquier 1992), the appearance of such bands is specific for the IR spectra of pure DNA. In this figure, the pure DNA spectrum reveals a broad absorption band around $3000-3400 \mathrm{~cm}^{-1}$ that could be assigned to several components of molecular vibrations, such as $\mathrm{N}-\mathrm{H}$-stretching modes, $\mathrm{C}=\mathrm{N}$ vibrations, $\mathrm{OH}$ symmetric, and antisymmetric stretching modes. The bands in the range of $1400-1800 \mathrm{~cm}^{-1}$ come from nucleobase vibrations and are extremely sensitive to base sets and base-pairing interactions. Broad bands in the range of $1600-1750 \mathrm{~cm}^{-1}$ include several stretching and bending mode $\left(\mathrm{C}=\mathrm{C}, \mathrm{C}-\mathrm{N}, \mathrm{C}=\mathrm{O}\right.$, and $\left.\mathrm{NH}_{2}\right)$ vibrations originating from base molecules. The main absorption bands observed are: $1603 \mathrm{~cm}^{-1}$ - the vibrations of $\mathrm{C}=\mathrm{N} 7$ of guanine, $1643 \mathrm{~cm}^{-1}$ - the vibration of $\mathrm{C} 2=\mathrm{O}$ of cytosine, and $1683 \mathrm{~cm}^{-1}$ - the vibrations of $\mathrm{C} 6=\mathrm{O}$ of guanine and $\mathrm{C} 4=\mathrm{O}$ of thymine (Taillandier et al. 1985; Taillandier 1990; Taillandier and Liquier 1992). The band at $1456 \mathrm{~cm}^{-1}$ usually is assigned to $\mathrm{C}=\mathrm{C}$-stretching vibration attributed to purine imidazole ring vibration.
The N-O-stretching vibration of secondary amine groups could be illustrated in the band at $1530 \mathrm{~cm}^{-1}$ (Silverstein et al. 2014). The region between 1500 and $1250 \mathrm{~cm}^{-1}$ could be used to obtain information about nucleoside-specific interaction and conformation. In this region, vibrations connected with base and base-sugar units give rise to marker bands. These markers are susceptible to glycosidic bond rotation, backbone conformation, and sugar-puckering modes.

The main absorption band at $1057 \mathrm{~cm}^{-1}$ could be attributed to vibrations of the -C-O-P sugar-phosphate chains. The $1250-1000 \mathrm{~cm}^{-1}$ region gives rise to reliable markers of backbone conformation (A-, B-, or Z-form) due to vibrations along the sugar-phosphate bone. In our experiments, DNA reveals a B-conformation as determined by the presence of the B-form marker band at $1221 \mathrm{~cm}^{-1}$ and the absence of either A-form or Z-form marker bands at $1240 \mathrm{~cm}^{-1}$ and at $1215 \mathrm{~cm}^{-1}$, respectively (Hackl et al. 2005). In addition, in the $800-900 \mathrm{~cm}^{-1}$ region, there are absorptions which can be assigned to vibrations of the sugar-phosphate groups (Hebda et al. 2011; Pawlicka et al. 2015; Lindqvist and Gräslund 2001; Banyay et al. 2003; Ting-Yu et al. 2011; Steckl et al. 2011) and are intense markers for the various sugar-puckering modes ( $\mathrm{N}$ - and $\mathrm{S}$ types). To assess the nature of the DNA-surfactant interactions, the conjugated samples were also characterized by FTIR spectroscopy. IR spectra for each IL-DNA complex are also shown in Fig. 2.

In all IL-DNA FTIR spectra, the following absorption bands appear: $3390 \mathrm{~cm}^{-1}-\mathrm{N}-\mathrm{H}$-stretching vibrations of

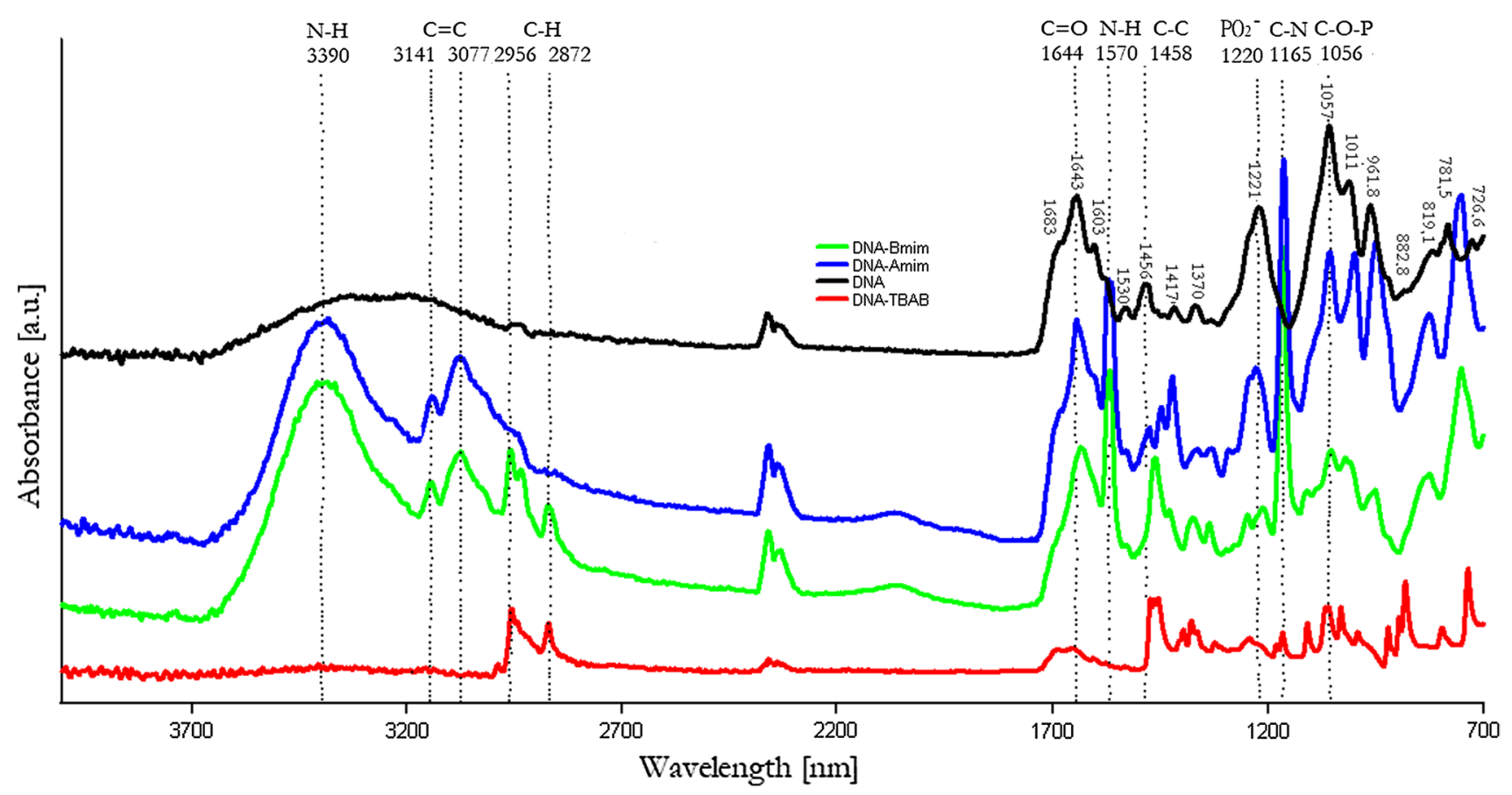

Fig. 2 FTIR spectra of DNA (-), DNA-Amim (blue line), DNA-Bmim (green line), and DNA-TBAB (red line) complexes 
imidazole ring, $3141 \mathrm{~cm}^{-1}$ and $3077 \mathrm{~cm}^{-1}-\mathrm{C}=\mathrm{C}$ the vibrations of imidazole ring, $2956 \mathrm{~cm}^{-1}$ and $2872 \mathrm{~cm}^{-1}$ symmetric and asymmetric stretching $\mathrm{C}-\mathrm{H}$ vibrations of the $-\mathrm{CH}_{2}$ and $-\mathrm{CH}_{3}$ groups, $1570 \mathrm{~cm}^{-1}-\mathrm{N}-\mathrm{H}$-deforming vibrations of imidazole ring, $1453 \mathrm{~cm}^{-1}$-bending vibrations of $-\mathrm{CH}_{2}$ group of aliphatic chains, and $1165 \mathrm{~cm}^{-1}-\mathrm{C}-\mathrm{N}$-stretching vibrations of ILs. The FTIR spectra clearly confirm the formation of DNA-ILs' complexes. The presence of the sugar absorption band at $1056 \mathrm{~cm}^{-1}$ and the lower signal in the carbonyl region of the bases also support the conclusion that the ILs are built into the helical DNA structure.

\section{High-performance size exclusion chromatography (HPSEC-MALLS-RI)}

The $M_{w}$ and $R_{\mathrm{g}}$ values for the DNA and DNA-ILs' samples are collated in Table S1. It is clearly seen that pure DNA exhibits higher values of $M_{w}$ and $R_{\mathrm{g}}$ than sonicated DNA. The average molecular mass for pure DNA (DNA') was $2.75 \times 10^{6} \mathrm{Da}$ and radii of gyration were measured as $80.0 \mathrm{~nm}$. Sonicated DNA chains (DNA) exhibited significantly lower values of $M_{w}\left(1.63 \times 10^{6}\right)$ and $R_{\mathrm{g}}(76.5 \mathrm{~nm})$ as compared to native DNA. According to the literature, data (Heckman et al. 2005) using of ultrasound reduce the molecular weight of DNA by fragmentation to give a Gaussiantype distribution of molecular weights.

Modification of DNA with ILs led to a further drop in $M_{w}$ and $R_{\mathrm{g}}$ values depending on the chemical composition of IL used for complexation. The lowest drop in $M_{w}\left(1.55 \times 10^{6}\right)$ and $R_{\mathrm{g}}(70.6 \mathrm{~nm})$ values was observed for DNA-TBAB complexes. Complexes of DNA with imidazole-based surfactants exhibited much lower molecular moments than DNA-TBAB complexes, indicating that interactions between DNA and surfactants mainly depend on the type of ionic liquid used for complexation. However, significant differences in $M_{w}$ and $R_{\mathrm{g}}$ values found for DNA-Bmim $\left(M_{w}=1.06 \times 10^{6}\right.$, $\left.R_{\mathrm{g}}=61.7 \mathrm{~nm}\right)$ and DNA-Amim $\left(M_{w}=0.81 \times 10^{6}\right.$, $R_{\mathrm{g}}=53.8 \mathrm{~nm}$ ) complexes, i.e., compounds containing the same type ionic liquid indicate that the side chain structure attached to the imidazole ring has an impact on the molecular structure of the complexes formed. Data from both RI and LS detectors provided calculations of differential molar mass distribution with the Astra 4.73.04 software. The differential molar mass distribution provides the amount of polymer (differential weight fraction) in a given molar mass interval.

Plots of differential weight fraction vs molar mass for DNA, sonicated DNA and DNA complexes studied are shown in Fig. 3. Clearly, the modification of DNA with ILs changed the distribution of molecular weight of the DNA chains.

Pure DNA sample exhibited much broader molecular weight distribution than sonicated DNA and each IL-DNA

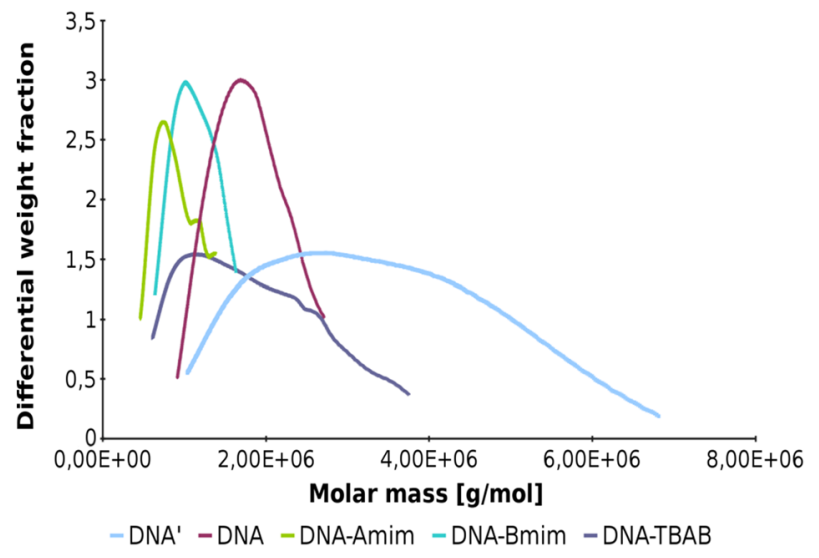

Fig. 3 Plots of differential weight fraction vs elution volume for DNA, sonicated DNA, and DNA complexes

complex. This means that the polydispersity of DNA is larger than that of all of the modified samples and sonication causes reduction in the molar mass dispersion. Modification of DNA with ILs, especially imidazole ring-containing ILs, gives more uniform material and leads to elimination of high-molecular weight chains. In addition, one could observe that the incorporation ILs into DNA lead to changes in DNA double-helical structure and makes DNA microfibers with a more compact structure. Complexes of DNA with ILs with an imidazole headgroup exhibited not only lower $M_{w}$ values as compared to the DNA-TBAB complex, but exhibited also significantly lower polydispersity. In the work of Dias et al (2004) and Dasgupta et al. (2007), it was suggested that DNA exhibits a discrete phase transition from coils to globules in the presence of cationic surfactant, with the structure and shape of aggregates depending on surfactant concentration. They concluded that the compaction of DNA depends on the variation of the chain length rather than on the headgroup structure. Longer chained surfactants (e.g., CTAB) are more efficient in compacting DNA than shorter chained surfactants.

\section{Scanning electron microscopy (SEM)}

Analyses of morphology of the prepared DNA-surfactant complexes was performed using a high-resolution JEOL 7550 equipped with TED (Transmission Electron Diffraction) and LEI (Lower Secondary Electron) detectors. The SEM images of DNA-surfactant films are presented in Fig. 4. The results obtained for DNA-TBAB complex are shown in Fig. $4 \mathrm{~b}$ and images of DNA-Bmim complex and DNA-Amim structure in Fig. 4c, d, respectively. The DNA alone is shown in Fig. 4a.

Images collected for DNA-Amim and DNA-Bmim complexes show the formation of microfiber-type structures. According to results obtained by Lee et al. (2008), 


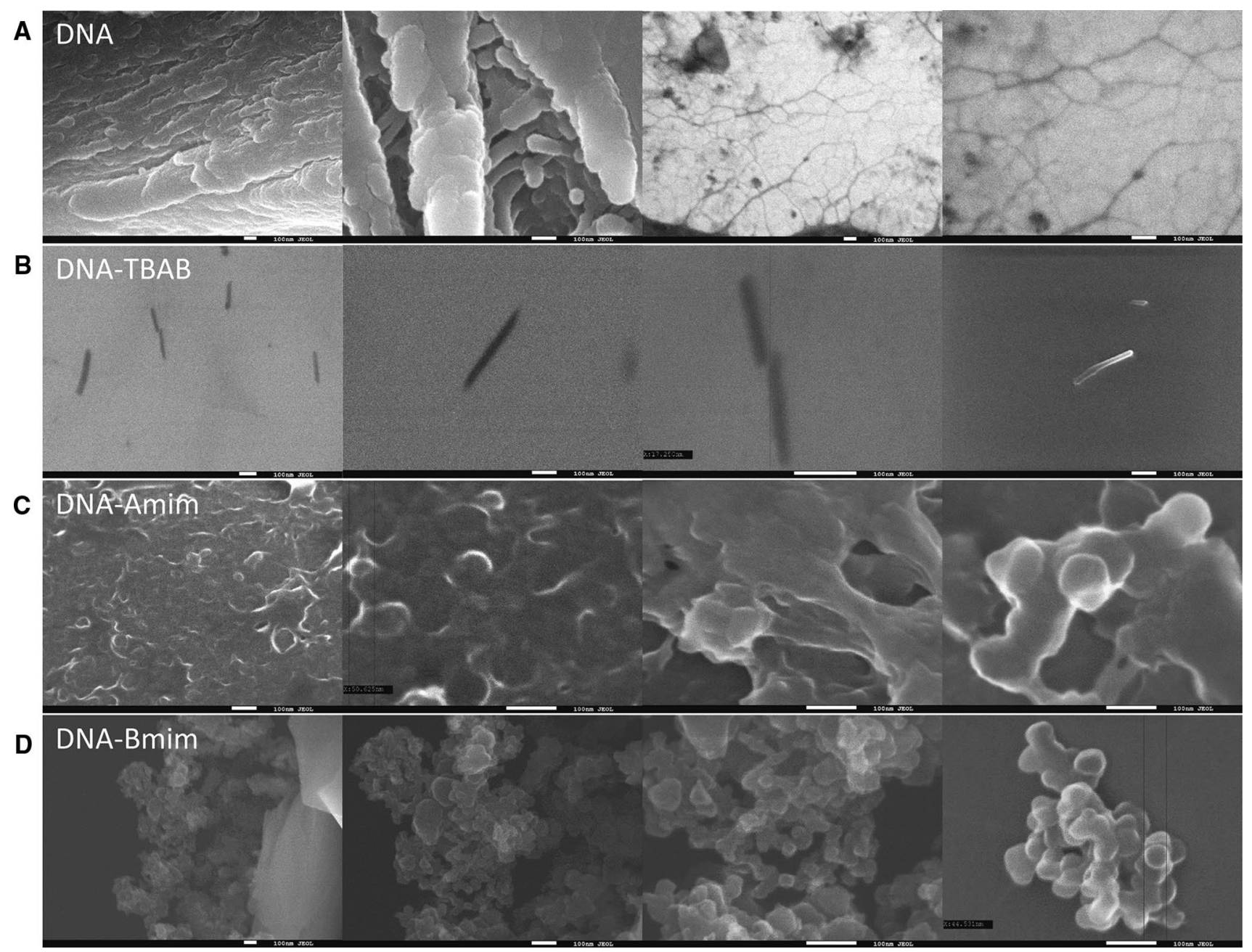

Fig. 4 SEM images of various DNA and DNA-surfactant films: DNA (a), DNA-TBAB (b), DNA-Bmim (c), and DNA-Amim (d). White bar in all cases $=100 \mathrm{~nm}$

native DNA hydrogels could form random entanglements to provide physically crosslinked networks. SEM pictures of DNA-TBAB composite show that DNA-TBAB chains create nanowires with different sizes. Such a phenomenon could be explained by the assumption that IL (TBAB) can bind to DNA backbone differently from Amim and Bmim to form a stable complex, intercalated within the DNA helical structure. This conclusion is supported by data obtained from chromatography experiments especially by $R_{\mathrm{g}}$ values of the DNA-TBAB complex, as shown in the Supporting information. The same type of nanowires could be produced for DNA modified with many agents in self-assembly methods (Choi et al. 2011).

\section{UV-Vis spectra}

Noting that DNA modified with quaternary surfactants, particularly CTMA (Cetyltrimethylammonium chloride), produces a transparent film with outstanding optical properties, e.g., high transmission in the full visible regime and NIR spectrum region (Pawlicka et al. 2015; Lin et al. 2011), we decided to use as DNA modifier another quaternary surfactant (TBAB) with shorter chain length (C4) and ionic liquids based on the imidazole ring. Figure 5 shows the optical properties of the DNA and synthesized DNA complexes in aqueous solution. The UV spectrum of the DNA used in this study on its own is identical with spectra reported for DNA double-helical structures in the literature. The first strong absorption peak of pure DNA below $230 \mathrm{~nm}$ originates from the overlapping electronic absorptions of phosphate groups and sugar moieties. The second absorption band at $\lambda_{\max } \sim 260 \mathrm{~nm}$ is attributed to the $\pi-\pi^{*}$ electronic transitions of the four heterocyclic bases in the nucleic acid (Kwon et al. 2012).

The UV-Vis absorption spectra in the $190-230 \mathrm{~nm}$ range of DNA imidazole-based ionic liquid complexes differ 


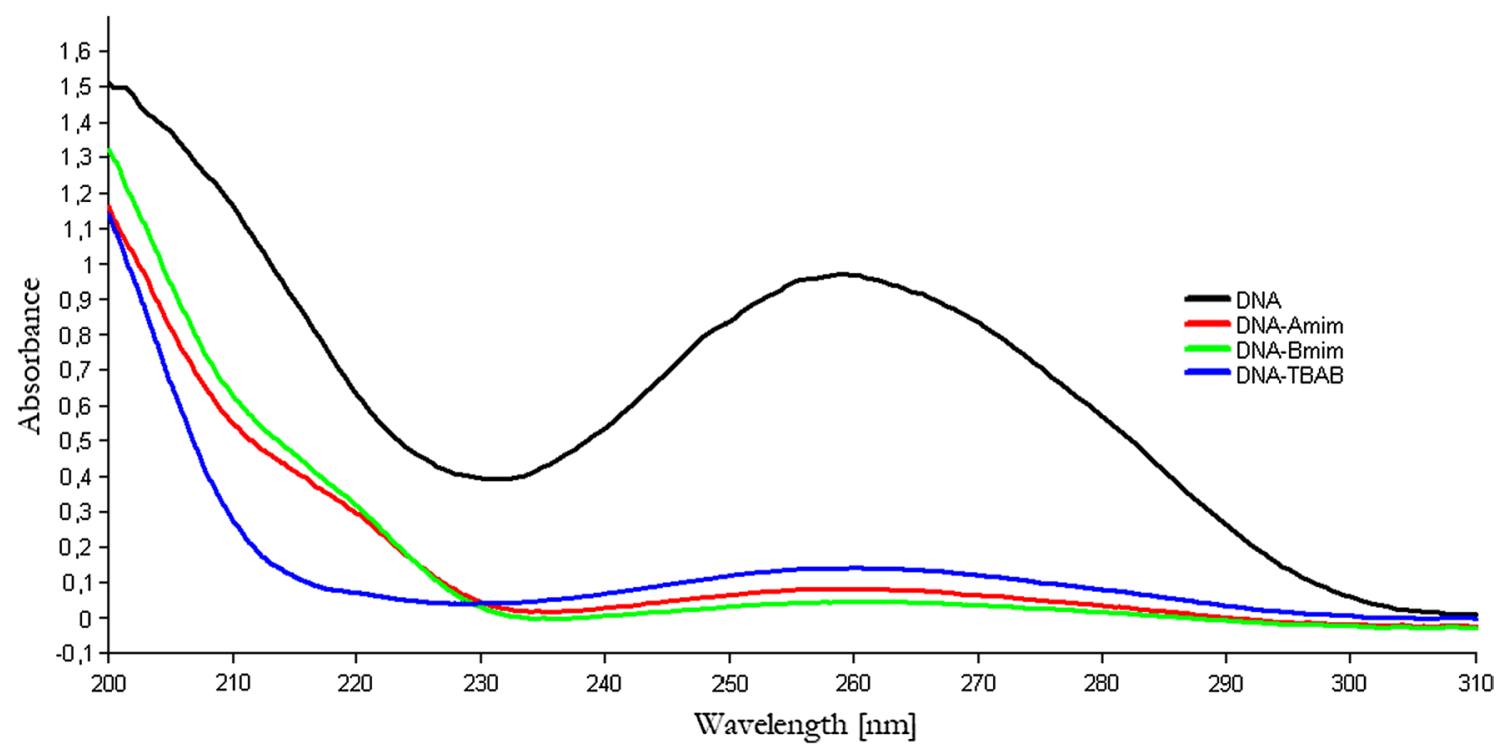

Fig. 5 UV-Vis absorbance of DNA and DNA-ILs' complexes

slightly from the spectrum of the DNA complex with quaternary ammonium salt IL; however, the maximum for all DNA-IL complexes is near $200 \mathrm{~nm}$. The second absorption band of synthesized DNA-IL complexes centered at $260 \mathrm{~nm}$ had significantly lower absorption than the same band registered for pure DNA. We suspect that this decrease in intensity peak absorption is a consequence of a reduction in the spatial order of polynucleotide strands, providing for a different $\pi-\pi$ stacking structure. Comparison of absorption spectra of pure DNA and $\mathrm{DNA}^{+} \mathrm{Q}^{-}$complexes in the shortwavelength region suggests that the absorption bands are more or less similar. These results indicate that the addition of ILs to DNA strands does not cause fundamental changes in the electronic structure of the original DNA backbone. The addition of ionic liquids into DNA solution caused a hypochromic effect on the absorption spectra at $260 \mathrm{~nm}$, without peak shift. These data correspond with observations by Guo et al. (2015) who observed gradually declined absorbance along with increasing surfactant concentration. It is known that hypochromic or hyperchromic effects are a peculiarity of DNA solutions when interaction with small molecules occurs. Hypochromic effects of DNA solutions could be the result of axial compression of DNA double helices caused by electrostatic binding and hydrophobic interactions. According to Sohrabi et al. (2013) a hypochromic effect without shift in UV-Vis spectra is assigned to external electrostatic and hydrophobic binding.

\section{Photoluminescent spectroscopy}

Fluorescence depends strongly on the environment in which chromophores are inserted and simultaneously on the molecular interactions with the polymer matrix (Pawlicka et al. 2015). DNA-related emission was previously attributed to the major contribution of the heterocyclic bases in the nucleic acids (Leones et al. 2013).

When excited with $310 \mathrm{~nm}$ wavelength radiation, all samples emitted light around $410 \mathrm{~nm}$.

As shown in Fig. S3, we collected fluorescence spectra for all DNA-IL complexes. Native DNA hardly displays any fluorescence. Moreover, incorporation of ionic liquids to DNA strands changes the intensity and shifts the maximum of the fluorescence peak. We observed a decrease in the emission maximum of the spectra of DNA and DNA complexes in the following order: DNA-Amim, DNA-Bmim, DNA-TBAB, and DNA, with the peak positioned at $416 \mathrm{~nm}$, $402 \mathrm{~nm}, 409 \mathrm{~nm}$, and $411 \mathrm{~nm}$, respectively. The greatest emission was observed for DNA-Amim and DNA-Bmim complexes.

\section{Circular dichroism spectra}

The circular dichroism spectra (CD) of pure DNA and DNA complexes are shown in Fig. 6.

The DNA spectrum shown in Fig. S4 clearly indicates that the native DNA sample exhibits a B-form conformation, confirming the results obtained by FTIR spectroscopy. Modification of DNA with ILs provided some bathochromic shifts in the conformation spectrum of DNA complexes. Equally cationic surfactants did not change the DNA backbone (B-form), maintaining this conformation. The bathochromic shifts in DNA-surfactant samples could be explained by the addition of compounds which are rich in double bonds or atoms with free electronic pairs. 
Fig. 6 Circular dichroism spectra of DNA and DNA complexes

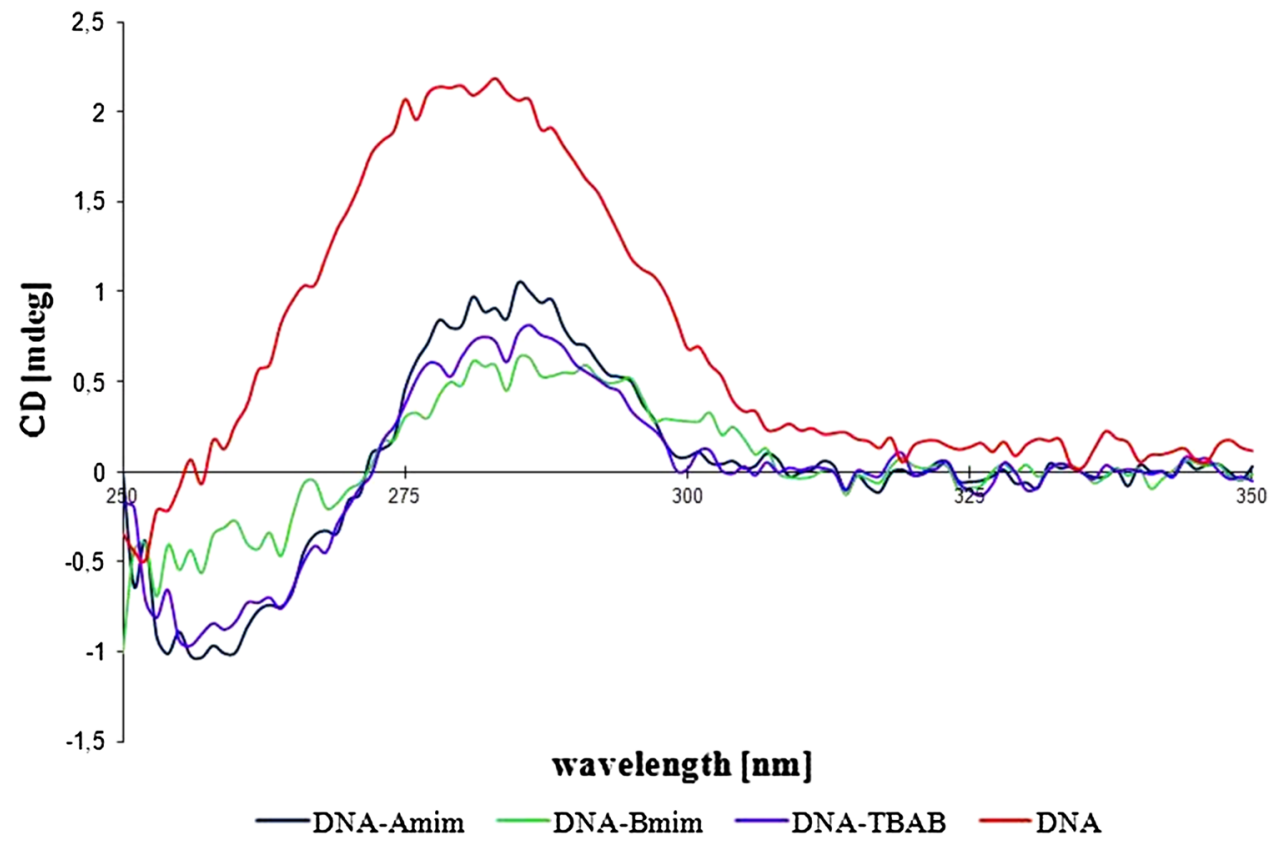

It is known that the binding of cations to DNA leads to condensed structure and changes in the amplitudes of CD bands (Lee et al. 2009). In agreement, Wang et al. (2001) suggest that a few water molecules bound during synthesis of DNA complexes are needed to retain the B-form conformation of DNA. We conclude that water molecules are one of the significant factors in stabilizing the DNA conformation (Privalov and Crane-Robinson 2017).

\section{X-ray diffraction (XRD)}

X-ray diffraction patterns of DNA, DNA-Amim, DNA-Bmim, and DNA-TBAB are presented in Fig. S5.

The DNA diffractogram shown in Fig. S5 reveals the presence of two very large bands attributed to the amorphous phase. The larger band is centered at $\Theta=27^{\circ}$ and smaller intensity broad band is centered at $\Theta=43^{\circ}$. XRD spectra of native DNA and DNA-surfactant complexes are identical and indicate that the inclusion of ILs does not change significantly the amorphous morphology of DNA. According to Leones et al. (Leones et al. 2013), ionic movements arise preferentially in amorphous structures rather than semicrystalline systems. The absence of a crystalline phase in DNA-IL complexes is advantageous due to its better optical, electrochemical and mechanical properties.

\section{Conclusions}

DNA is an important biological polymer and the basis of genetic information. It is highly interesting as a functional nanosize material due to its unique features that cannot be found in other polymers. DNA-IL complexes have been successfully prepared as stable, homogeneous gels. The onset of surfactant binding to DNA does not vary significantly with the architecture of the headgroup. DNA-IL complexes, especially those with imidazole ring-containing ILs, exhibit lower $M_{w}$ and $R_{\mathrm{g}}$ values than native DNA. Due to elimination of longer DNA chains during complexation, the resulting DNA-IL molecules show lower polydispersity and more compact structures than native DNA chains with a change in the DNA double-helical structure. UV and photoluminescent experiments show that the resulting complexes have different optical properties compared to pure DNA. An increase in photoluminescent properties could provide DNA-surfactant complexes with the potential to be used in sensing applications. Taking into account the results presented in this paper, we conclude that the obtained complexes may be applied in nonlinear optics. Optical methods, e.g., light absorption, fluorescence, luminescence, and reflectance, applicable in optical biosensors (Long et al. 2013), are the most frequently used in detection as an alternative to conventional analytical techniques. Due to their advantages, DNA biosensor technologies are rapidly developing as an alternative to the classical gene assays (Siddiquee et al. 2014), selective detection of DNA hybridization (Sassolas et al. 2008), and monitoring of pollutants without extensive sample preparation (Long et al. 2013). Potential applications of DNA biosensors include molecular diagnostics, pharmacogenomics, drug development, medical diagnosis, food analysis, pollution (Cagnin et al. 2009), biomedical research, and environmental monitoring (Long et al. 2013). Ionic liquids could be used as a part of electrochemical DNA biosensor. ILs are widely used as modifiers on electrode surfaces in the 
fabrication of electrochemical properties (Siddiquee et al. 2014). Siddiquee et al. (2014) explored the selectivity of an IL modified DNA electrochemical biosensor by measuring its responses towards different gene sequences related to the Trichoderma genus. The electrochemical DNA biosensors were also used to for the detection of Mycobacterium tuberculosis (Mohamad et al. 2017). The integration of nanomaterials and functional biological molecules as in nucleic acids is a relatively new field for optical biosensors and we have shown that novel complexes formed by DNA with the ionic liquids Amim, Bmim, and TBAB are promising materials for such applications (Long et al. 2013).

Funding This research did not receive any specific grant from funding agencies in the public, commercial, or not-for-profit sectors.

Open Access This article is distributed under the terms of the Creative Commons Attribution 4.0 International License (http://creativeco mmons.org/licenses/by/4.0/), which permits unrestricted use, distribution, and reproduction in any medium, provided you give appropriate credit to the original author(s) and the source, provide a link to the Creative Commons license, and indicate if changes were made.

\section{References}

Aga RS Jr, Telek BA, Lombardi JP III, Heckman EM, Bartsch CM (2013) Dielectric tunability of DNA biopolymer films with varying amounts of hexadecyltrimethylammonium chloride. J Electron Mater 42:463-469

Banyay M, Sarkar M, Gräslund A (2003) A library of IR bands of nucleic acids in solution. Biophys Chem 104:477-488

Bello-Perez LA, Paredes-Lopez O, Roger P, Colonna P (1996) Molecular characterization of some amylopectins. Cereal Chem 73:12-17

Cagnin S, Caraballo M, Guiducci C, Martini P, Ross M, SantaAna M, Danley D, West T, Lanfranchi G (2009) Overview of electrochemical DNA biosensors: new approaches to detect the expression of life. Sensors 9:3122-3148

Choi W, An T, Lim G (2011) Fabrication of conducting polymer nanowires, nanowires-implementations and applications. In: Hashim A (ed) InTech, Chapter 19, pp 439-454. https://doi. org/10.5772/16765

Costa D, Morán MC, Miguel MG, Lindman B (2008) Cross-linked DNA gels and gel particles. In: RS Dias, Lindman B (eds) DNA interactions with polymers and surfactants. Wiley Interscience, New Jersey

Cui L, Zhu L (2006) lamellar to inverted hexagonal mesophase transition in dna complexes with calamitic, discotic, and cubic shaped cationic lipids. lamellar to inverted hexagonal mesophase transition in dna complexes with calamitic, discotic, and cubic shaped cationic lipids. Langmuir 22:5982-5985

Cui L, Miao J, Zhu L (2006) Spacer Length controlled oblique-columnar to lamello-columnar mesophase transition in liquid crystalline DNA-discotic cationic lipid complexes. Macromolecules 39:2536-2545

Cui L, Chen D, Zhu L (2008) Conformation transformation determined by different self-assembled phases in a DNA complex with cationic polyhedral oligomeric silsesquioxane lipid. ACS Nano 2:921-927
Dasgupta A, Das PK, Dias RS, Miguel MG, Lindman B, Jadhav VM (2007) Effect of headgroup on DNA-cationic surfactant interactions. J Phys Chem B 111:8502-8508

Dias RS, Pais AACC, Miguel MG, Lindman B (2004) DNA and surfactants in bulk and at interfaces. Coll Surface A 250:115-131

Gajria S, Neumann T, Tirrell M (2011) Self-assembly and applications of nucleic acid solid-state films. WIREs Nanomed Nanobiotechnol. 3:479-500

Grote JG, Diggs DE, Nelson RL, Zetts JS, Hopkins FK, Ogata N (2005) DNA photonics [deoxyribonucleic acid]. Mol Cryst Liq Cryst 426:3-17

Guo L, Zhang Z, Qiao H, Liu M, Shen M, Yuan T (2015) Spectroscopic study on interaction between three cationic surfactants with different alkyl chain lengths and DNA. Spectrochim Acta A 151:237-246

Hackl EV, Kornilova SV, Blagoi YP (2005) DNA structural transitions induced by divalent metal ions in aqueous solutions. Int J Biol Macromol 35:175-191

Hagen JA, Li W, Steckl AJ, Grote JG (2006) Enhanced emission efficiency in organic light-emitting diodes using deoxyribonucleic acid complex as an electron blocking layer. Appl Phys Lett 88:171109

Hagen JA, Li W-X, Spaeth H, Grote JG, Steckl AJ (2007) Molecular beam deposition of DNA nanometer films. Nano Lett 7:133-137

Hanselmann R, Burchard W, Ehrat M, Widmer HM (1996) Structural properties of fractionated starch polymers and their dependence on the dissolution process. Macromolecules 29:3277-3282

Hebda E, Niziol J, Pielichowski J, Sniechowski M (2011) Properties of DNA complexes with new cationic surfactants. Chem Chem Technol 5:397-402

Heckman EM, Hagen JA, Yaney PP, Grote JG, Hopkins FK (2005) Processing techniques for deoxyribonucleic acid: Biopolymer for photonics applications. Appl Phys Lett 87:211115

Hung Y-Ch, Lin T-Y, Hsu W-T, Chiu Y-W, Wang Y-S, Fruk L (2012) Functional DNA biopolymers and nanocomposite for optoelectronic applications. Opt Mater 34:1208-1213

Jumbri K, Abdul Rahman MB, Abdulmalek E, Ahmad H, Micaelo NM (2014) An insight into structure and stability of DNA in ionic liquids from molecular dynamics simulation and experimental studies. Phys Chem Chem Phys 16:14036-14046

Jumbri K, Ahmad H, Abdulmalek E, Abdul Rahman MB (2016) Biophysical properties of DNA in hydrated ionic liquids. AIP Conf Proc 1787:070003-1-070003-7

Kitazawa N, Miyagawa S, Date K, Aroonjaeng W, Aono M, Watanabe Y (2009) Optical properties of dye-doped deoxyribonucleic acid films. J Mater Sci 44:4999-5003

Krupka O, El-Ghayoury A, Rau I, Sahraoui B, Grote JG, Kajzar F (2008) NLO properties of functionalized DNA thin films. Thin Solid Films 516:8932-8936

Kwon Y-W, Choi DH, Jin J-I (2012) Optical, electro-optic and optoelectronic properties of natural and chemically modified DNAs. Polym J 44:1191-1208

Lee CK, Shin SR, Lee SH, Jeon J-H, So I, Kang TM (2008) DNA hydrogel fiber with self-entanglement prepared by using an ionic liquid. Angew Chem Int Edit 120:2504-2508

Lee CK, Shin SR, Mun JY, Han S-S, So I, Jeon J-H (2009) Tough supersoft sponge fibers with tunable stiffness from a dna selfassembly technique. Angew Chem Int Edit 48:5116-5120

Leones R, Rodrigues LC, Fernandes M, Ferreira RAS, Cesarino I, Pawlicka A (2013) Electro-optical properties of the DNA-Eu ${ }^{3+}$ bio-membranes. Electroanal Chem 708:116-123

Lin T-Y, Chang C-Y, Lien Ch-H, Chiu Y-W, Hsu W-T, Su Ch-H, Wang Y-S, Hung Y-Ch (2011) Preparation and characterization of DNAaromatic surfactant complexes for optoelectronic applications. Proc SPIE 7935:79350E-E79351 
Lindman B, Antunes F, Aidarova S, Miguel M, Nylander T (2014) Polyelectrolyte-surfactant association-from fundamentals to applications. Coll J 76:585-594

Lindqvist M, Gräslund A (2001) An FTIR and CD study of the structural effects of G-tract length and sequence context on DNA conformation in solution. J Mol Biol 314:423-432

Long F, Zhu A, Shi H (2013) Recent advances in optical biosensors for environmental monitoring and early warning. Sensors 13:13928-13948

Mohamad FS, Zaid MHM, Abdullah J, Zawawi RM, Lim HN, Sulaiman Y, Rahman NA (2017) Synthesis and characterization of polyaniline/graphene composite nanofiber and its application as an electrochemical dna biosensor for the detection of mycobacterium tuberculosis. Sensors 17:2789

Nowak E, Khachatryan G, Polit A, Krzeminska-Fiedorowicz L, Dziedzicka-Wasylewska M, Fiedorowicz M (2012) Stimulation of Selected cellulases from Trichoderma reese $i$ with white linearly polarized light. Open J Org Poly Mat 2:45-52

Pawlicka A, Oliveira HCL, Kajzar F, Kanicki J (2015) Properties of DNA-based organic dyes doped membranes. Display Imaging $1: 225-238$

Pratap Reddy MS, Puneetha P, Lee Y-W, Jeong S-H, Park Ch (2017) Fabrication and electrical characterization of Al/DNA-CTMA/ptype a-Si: H photodiode based on DNA-CTMA biomaterial. Electron Mater Lett 13:9-15

Privalov PL, Crane-Robinson C (2017) Role of water in the formation of macromolecular structures. Eur Biophys J 46(3):203-224

Rau I, Czaplicki R, Derkowska B, Sahraoui B (2011) Nonlinear optical properties of functionalized DNA-CTMA complexes. Nonlinear Opt Quantum Opt 43:283-323

Sahraoui B, Pranaitis M, Gindre D, Niziol J, Kažukauskas V (2011) Opportunities of deoxyribonucleic acid complexes composites for nonlinear optical applications. J Appl Phys 110:83117

Sassolas A, Leca-Bouvier BD, Blum LJ (2008) DNA biosensors and microarrays. Chem Rev 108:109-139

Siddiquee S, Rovina K, Yusof NA, Rodrigues KF, Suryani S (2014) Nanoparticle-enhanced electrochemical biosensor with DNA immobilization and hybridization of Trichoderma harzianum gene. Sens Bio-Sens Res 2:16-22

Silverstein RM, Webster FX, Kiemle D (2014) Chapter 2. In: Yee J, Keohane E (eds) Spectrometric identification of organic compounds, 8th edn. Wiley, New York

Sivapragasam M, Moniruzzaman M, Goto M (2016) Recent advances in exploiting ionic liquids for biomolecules: solubility, stability and applications. Biotechnol J 11:1000-1013

Smirnova NA, Safonova EA (2012) Micellization in solutions of ionic liquids. Coll J 74:254-265
Sohrabi B, Khani V, Moosavi-Movahedi AA, Moradi P (2013) Investigation of DNA-cationic bolaform surfactants interaction with different spacer length. Coll Surface B 110:29-35

Steckl AJ (2007) DNA - a new material for photonics? Nat Photonics $1: 3-5$

Steckl AJ, Spaeth H, You H, Gomez E, Grote J (2011) DNA as an optical material. J Opt Photonics News 22:34-39

Subramanyam G, Mathala P, Chevalier C, Davis A, Yaney P, Grote J (2003) Microwave characterization of electro-optic polymers. Proc Mater Res Soc 734:249-254

Sun Q, Subramanyam G, Dai L, Check M, Campbell A, Naik R (2009) highly efficient quantum-dot light-emitting diodes with DNACTMA as a combined hole-transporting and electron-blocking layer. ACS Nano 3:737-743

Taillandier E (1990) In: Sarma RH, Sarma MH (eds) Structure and methods, vol 3. Adenine Press, Albany, pp 73-78

Taillandier E, Liquier J (1992) Infrared spectroscopy of DNA. Method Enzymol. 211:307-335

Taillandier E, Liquier J, Taboury JA (1985) Advances in infrared and raman spectroscopy. In: Clark RJH, Hester RE (eds) Wiley/Heyden, New York, Chapter 12, pp 65-114

Ting-Yu L, Chia-Yun Ch, Chien-Hsiang L, Yi-Wen Ch, Wei-Ting H, Che-Hsuan S (2011) Preparation and characterization of DNAaromatic surfactant complexes for optoelectronic applications. In: Nelson RL, Kajzar F, Kaino T, Koike Y (eds) Organic photonic materials and devices XIII, Proc. SPIE 7935:79350

Wang LL, Yoshida J, Ogata N (2001) Self-assembled supramolecular films derived from marine deoxyribonucleic acid(DNA)-cationic surfactant complexes: large-scale preparation and optical and thermal properties. Chem Mater 13:1273-1281

Yu Z, Li W, Hagen JA, Zhou Y, Klotzkin D, Grote JG (2007) Photoluminescence and lasing from deoxyribonucleic acid (DNA) thin films doped with sulforhodamine. Appl Opt 46:1507-1513

Zalar P, Kamkar D, Naik R, Ouchen F, Grote JG, Bazan GC (2011) DNA electron injection interlayers for polymer light-emitting diodes. J Am Chem Soc 133:11010-11013

Zhao H (2015) DNA stability in ionic liquids and deep eutectic solvents. J Chem Technol Biotechnol 90:19-25

Publisher's Note Springer Nature remains neutral with regard to jurisdictional claims in published maps and institutional affiliations. 